\title{
Strengthening Financial Capability of a Municipality: A Case Study of Dhaka City Corporation
}

\author{
Rokshana Binta Samad*
}

\begin{abstract}
The universal complaint that the Urban Local Bodies (ULBs) i.e. City Corporations and Municipalities (Pourashavas in Bangladesh) in developing countries are in dire need of resources not only for investment to meet the increasing demand of growing urban population but also for maintenance of the existing services. Municipal finance in Bangladesh has so far not been extensively studied. For this research, Dhaka City Corporation (DCC) has been chosen for a case study. The research has investigated on how the financial capability of City Corporation can be strengthened. Investigation was made on various sources of revenue, existing state of tax base, and various problems pertaining to income and expenditure of Dhaka City Corporation. The study has explored potential sources of financing and made some suggestions to enhance local initiatives in strengthening financial capability.
\end{abstract}

\section{Introduction}

Local government can be defined as - infra sovereign units within a sovereign nation employed for specific functions in their jurisdiction (Tareque, 1995). There are two distinct kinds of local government institutions in Bangladesh - one for the rural areas and another for urban areas. The two types of urban local government systems, namely City Corporations and Pourashavas can be considered as the most surviving local government units. It can be envisaged that the Municipality/City Corporation is the vital body working for development at the urban local level in Bangladesh. Finance is the key pillar to implement development initiatives. The universal complaint that the Urban Local Bodies (ULBs) in developing countries are in dire need of resources not only for investment to meet the increasing demand of growing urban population but also for maintenance of the existing services. The ability of the ULBs in Bangladesh to raise revenues is far too short because of the overall poverty of the population. The ULBs also fail to make the reluctant inhabitants pay taxes. All the ULBs have outstanding dues and poor collection status leaving out the low-income areas. With meager resources and funding from the government, there is a serious need for sustainable municipal finance strategies without further delay.

Studies on Municipal finance in Bangladesh are few and far between (Mondol, 1987). Focusing on Dhaka City Corporation (DCC), this paper intends to investigate on the sources of municipal funding and nature of its expenditures. It also explores the possible new sources of municipal funding and examines how these new sources of funds can be used for strengthening the financial capability of a municipality.

\section{Sources of Revenue}

The resource of the city corporation is composed of internally raised revenue, government and foreign grants and loan and advances. Internal revenue includes several taxes, rates for the provision of municipal services, fees, fines, tolls, rents from own property, and key money and monthly rentals of market stalls. The tax revenue sources are those on the annual rental value of buildings and land, popularly called holding tax, on the transfer of immovable property, on professions, trades and callings, on entertainment, non-motorized vehicles, animals, advertisements, and on births, marriages, adoptions and feasts. Tax on annual rental value of 
building and land can be imposed at the maximum rate of seven percent per annum which the corporation has imposed on the inhabitants. Government grants include normal or salary compensation grant, octroi compensation grant and development grant. Octroi tax was abolished from 1981-82 and the government has since been providing a grant in lieu of the estimated annual income from octroi. Now a fixed amount of money is given to the City Corporation by Local Government Engineering Department (LGED) which is very nominal. Development grant is provided against different projects submitted by the City Corporation to the government. Some projects are also financed by donor assistance.

\section{Analysis of Revenue Collection}

City Corporation generally selects those items which are expected to fetch a reasonable income without working unnecessary irritants to the public. Some of the revenue item depending on their major share of percentage to the total income has been discussed here.

Table 1: Collection of revenue (figure in thousand) from various sources according to budget from fiscal year 2001-02 to 2005- 06

\begin{tabular}{|l|c|c|c|c|c|}
\hline \multirow{2}{*}{\multicolumn{1}{c|}{ Item of Revenue }} & \multicolumn{5}{c|}{ Financial Year } \\
\cline { 2 - 6 } & $2001-02$ & $2002-03$ & $2003-04$ & $2004-05$ & $2005-06$ \\
\hline Own revenue source & $39.2 \%$ & $44.21 \%$ & $38.45 \%$ & $33.01 \%$ & $49.02 \%$ \\
\hline Others & $1.01 \%$ & $.02 \%$ & $.16 \%$ & $.024 \%$ & ---- \\
\hline Government grant & $12.59 \%$ & $10.46 \%$ & $6.6 \%$ & $7.49 \%$ & $8.1 \%$ \\
\hline Special Government grant & ---- & $6.44 \%$ & $7.26 \%$ & $4.42 \%$ & $3.93 \%$ \\
\hline $\begin{array}{l}\text { Govt. Private investment and foreign } \\
\text { added project }\end{array}$ & $47.2 \%$ & $38.86 \%$ & $47.52 \%$ & $55.06 \%$ & $38.95 \%$ \\
\hline
\end{tabular}

Source: Field survey, 2009

From Table 1, it can be seen that Government grant has not been a major source of finance for Dhaka City Corporation. It formed only $12.59 \%$ of total resources in $2001-02$, falling to $10.46 \%$ in 2002-03 and then declined further in the later years. Comparing with the government grant, percentage of revenue from own sources are in better position. In 2001-02 financial year, the share of own revenue was $39.2 \%$ of the total resources of Dhaka City Corporation, but in 2005-06, it rose to $49.02 \%$ within a period of five years. The income from the external sources (i.e. from GOB and the foreign donors) has also been fluctuating. The income from this source was more or less same between 2002-03 and 2005-06. The percentage of special government grant is also nominal of the percentage share of the total resources. In certain years, the proportion of grant increases due to the existence of some large scale Goverment/Foreign Aided Projects. For example, Environmental Improvement Project in 2003-04 and Improvement of Infrastructure in different areas of Dhaka City in 2005-06 injected an extra fund to city's development activities.

\section{Holding Tax (Including Conservancy and Lighting Rate)}

The holding tax which is a form of property tax can be traced back to the time of the Romans. The term 'holding tax' encompasses an array of property based taxes and rates levied against the value of buildings and the land upon which they are situated. It comprises the house tax, lighting rate, and conservancy rate. This was historically the most important and stable source of municipal revenue. Recently, other sources have become more important. But still holding tax has got the largest potential for growth if properly handled. 
Table 2 provides information on demand and collection of holding tax for several years beginning from 1999-2000. This shows that the volume of holding tax demand has increased in the seven year period. The current demand gives the actual annual demand of tax for all the holdings in the Corporation area. The total demand of this tax was 106 crore in 1999-2000 which has largely increased to 210 crore in 2005-2006. Holding tax collection figures in Table 2 show that collection to demand ratio substantially improved in three years starting from 19992000 to $2001-2002$. The percentage shares were respectively $74.56 \%, 81.27 \%$, and $74.28 \%$ for these years.The holding tax collection was low for 2002-03 to 2005-06. The reason behind the poor collection is unpaid arrear, under assessment etc. Unpaid arrears accumulating over the years, is a major problem in financial management of the municipalities in Bangladesh.

Table 2: Demand and collection status of holding tax

\begin{tabular}{|c|c|c|c|c|}
\hline Financial year & Holding number & $\begin{array}{c}\text { Demand according } \\
\text { to budget }\end{array}$ & $\begin{array}{c}\text { Collection according to } \\
\text { balance sheet }\end{array}$ & \% of collection \\
\hline $1999-2000$ & 170354 & 1060000000 & 790317356.46 & 74.56 \\
\hline $2000-2001$ & 174094 & 1100000000 & 893954105.21 & 81.27 \\
\hline $2001-2002$ & 178241 & 1250000000 & 928549372.58 & 74.28 \\
\hline $2002-2003$ & 183986 & 1600000000 & 1096782726.24 & 68.55 \\
\hline $2003-2004$ & 190265 & 1700000000 & 1179126846.66 & 69.36 \\
\hline $2004-2005$ & 197296 & 2000000000 & 1173365948.00 & 58.67 \\
\hline $2005-2006$ & Around 200000 & 2100000000 & 1313728666.93 & 62.56 \\
\hline
\end{tabular}

Source: Field survey, 2009

\section{Property Transfer Fee}

This tax is levied when any sale or other transfer of immovable property (land, building, etc.) takes place within the City Corporation. The tax is levied at $2 \%$ of the value of the property, which is actually collected by the agencies under the Ministry of Land and after deduction of collection charges passed on to the Corporation concerned. This is actually not a local tax. It is levied and collected along with a variety of stamp duties. While there is apparently little problem in realizing the Corporations' share of the tax, the rate at which it is levied is very low (Asaduzzaman, 1998).

Figure 1 presents the total property transfer fees for five financial years, which shows that in the financial year 2001-02, the collection of property transfer fees are only Taka 36000 (in thousand). The collection from fees has improved significantly from Taka 36000 to Taka 315000 in 2005-06. Collection performance has improved somewhat better in five years.

\section{Trade License Fees}

Trade license fees are one of the non property taxes and are levied on various trades (shopkeepers, various businesses). From Figure 2, it can be seen that the collection performance in current and current surcharge is better in position than arrear and arrear surcharge collection. In the fiscal year 2005-06 current and current surcharge collection from trade license has a comparatively better collection efficiency which is $64.24 \%$ in comparison with the arrear surcharge collection, which is only $21.13 \%$ of the total arrear fees in the same year.

\section{Rickshaw License and Road Cutting Fees}

Rickshaws remain the main source of transport for many people. This source, therefore, may be a quite buoyant one (Asaduzzaman, 1998). But the general impression is that there are more 


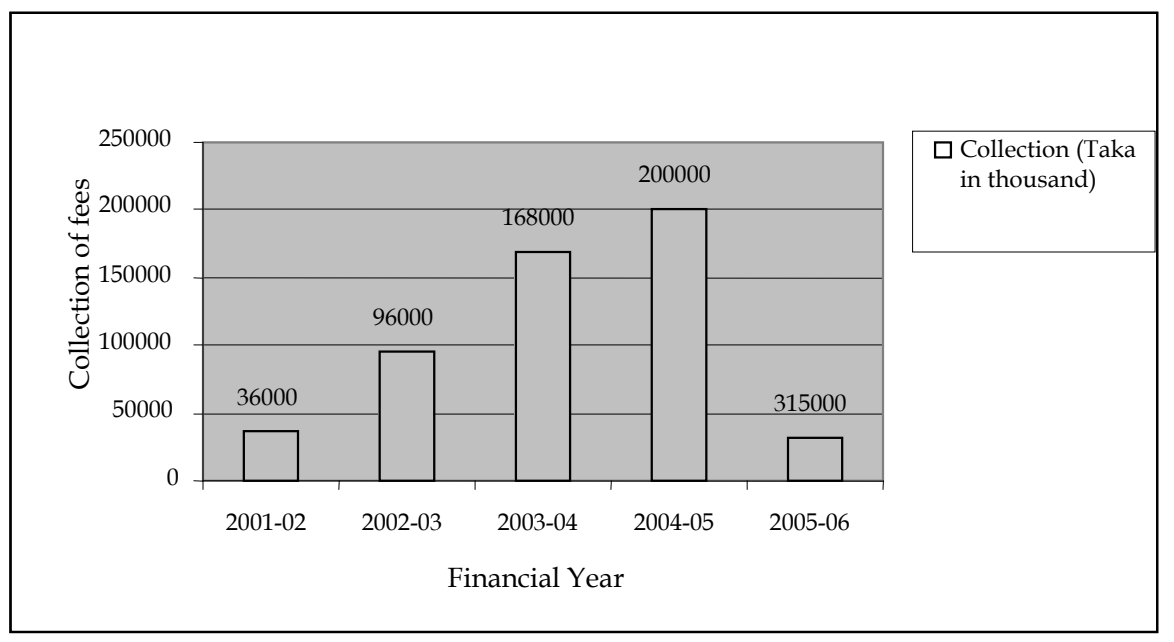

Source: Field survey, 2009

Fig.1: Property Transfer Fees Collection Status in the Fiscal Year from 2001-02 to 2005-06

rickshaws on the street than are licensed for. Various fees are charged by the City Corporation. Road cutting fees are one of them. An important fee in many Municipalities/City Corporations is that charged to utilities which cut roads for such purposes as laying the pipelines. Such revenues are, however, offset by the costs of repairing the roads and, therefore, cannot be viewed as a major net revenue source.

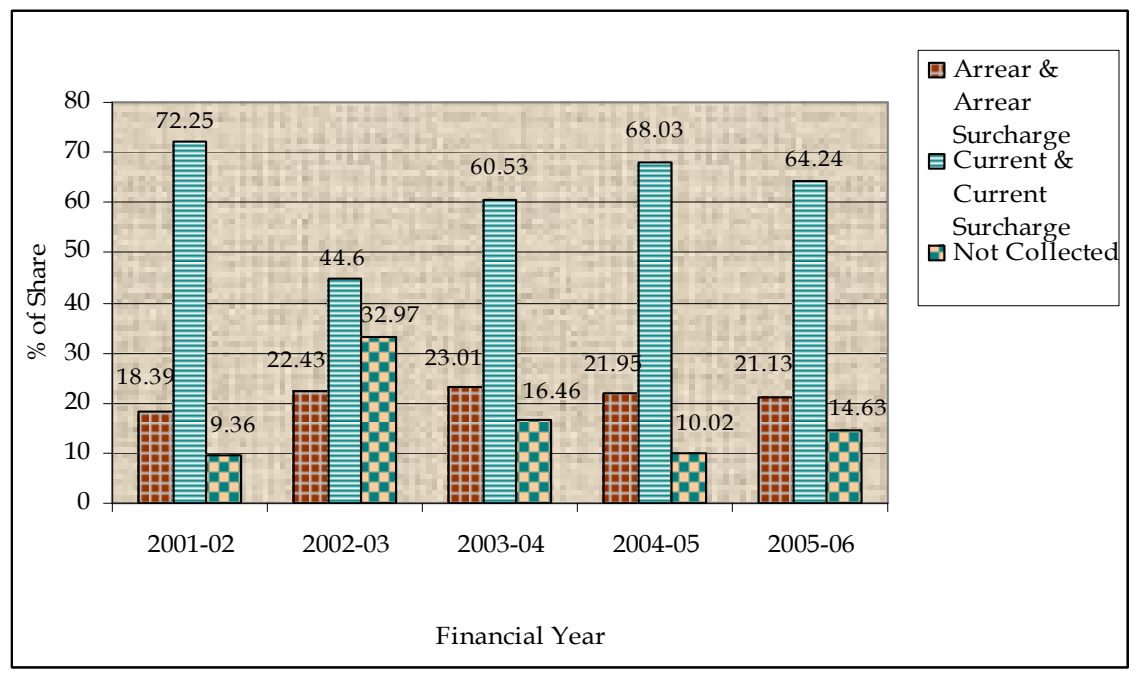

Source: Field survey, 2009

Fig. 2: Collection Performance of Trade License Fees

Table 3 presents some data of rickshaw license fees and road cutting fees for the five financial years. The demand figure for road cutting fees is quite larger than the rickshaw license fees demand. In the financial years 2001-02, 2002-03 and 2005-06, in case of rickshaw license fees, the collection efficiency indicates that a significant amount was earned from this sector. In case of Road cutting fees the collection efficiency was poor at the starting of the financial year 2001-2002. 
Table 3: Revenue Collections from Rickshaw License Fees \& Road Cutting Fees (in thousand)

\begin{tabular}{|l|c|c|c|c|c|c|}
\hline \multirow{2}{*}{$\begin{array}{l}\text { Financial } \\
\text { year }\end{array}$} & \multicolumn{3}{|c|}{ Rickshaw License Fees } & \multicolumn{3}{c|}{ Road Cutting Fees } \\
\cline { 2 - 7 } & Demand & Collection & $\begin{array}{c}\% \text { of } \\
\text { collection }\end{array}$ & Demand & Collection & $\begin{array}{c}\% \text { of } \\
\text { collection }\end{array}$ \\
\hline $2001-2002$ & 25800 & 20160 & 78.14 & 60000 & 40284 & 67.14 \\
\hline $2002-2003$ & 20000 & 14978 & 74.89 & 150000 & 118845 & 79.23 \\
\hline $2003-2004$ & 42600 & 34182.24 & 80.24 & 50000 & 40960 & 81.92 \\
\hline $2004-2005$ & 60000 & 40000 & 66.67 & 200000 & 168060 & 84.03 \\
\hline $2005-2006$ & 17500 & 15634.5 & 89.34 & 300000 & 280000 & 93.33 \\
\hline
\end{tabular}

Source: Field survey, 2009

But the collection efficiency of the fees was improved from the 2002-03 financial year, and from then, the City Corporation had stared to enhance its collection and the increasing trend was moderately high. At the end of the financial year 2005-06, the demand for road cutting fees has gained around $93.33 \%$ collection efficiency.

\section{Rent From Property/Market}

Rental income particularly from shops and markets owned by the City Corporations, constitute a very important source of revenue. Revenue from rent increased due to enhancement of rates and inclusion of new shops in the in the register. The revenue accrues from rental key-proceeds (Salami) of market stalls, rent of buildings, sale of land. From 1984-85, the City Corporations undertook a major scheme to upgrade and/or construct modern markets in different parts of the city. In case of upgrading of an existing market, the incumbent shopkeepers were allowed market stalls at preferential rates. Additional stalls were let out at market rates to new ownerships.

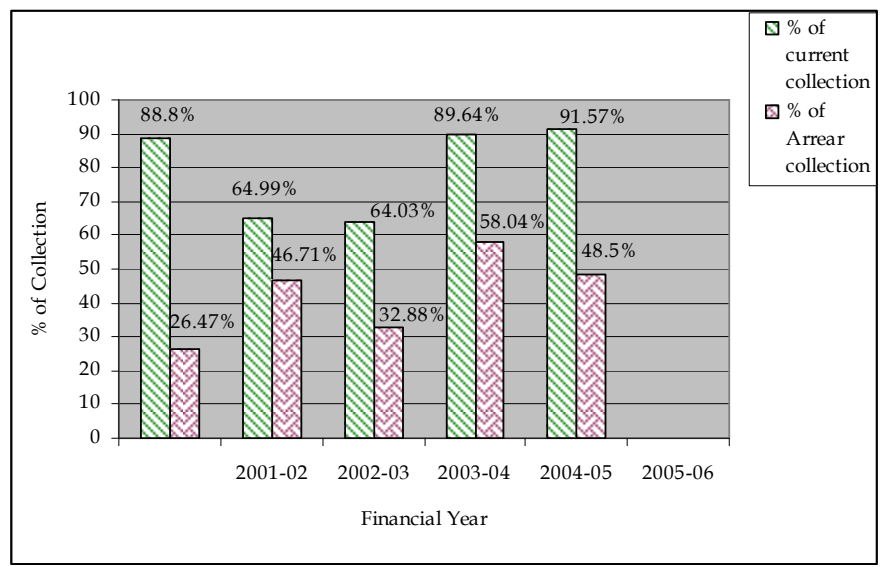

Source: Field survey, 2009

Fig. 3: Trend of Market Rent Collection

Figure 3 shows that the current collection efficiency of market rent (salami, mutation) against the current demand had gained maximum at $91.57 \%$ in the financial year of 2005-06. In the financial year 2002-03 to 2004-05, the rent collection presents lower efficiency. The arrear collection in the financial year 2004-05 has gained at 58.04\% which presents poor collection but comparatively 
better than other financial year arrear collection. There are various reasons for the ups and downs in the amount of rent collection. Case 1: When in some market, a sort of litigation is going on, then the City Corporation does not get any rent from that market. After finishing the litigation case, the Corporation gets large amount of money for several years as an arrear collection. Case 2: the Corporation collects huge rent in case of building new market and at the same time demand also rises. Case 3: the demand for rent collection also falls when the market are breaking down.

\section{Expenditure Pattern}

The expenditure of the Dhaka City Corporation has been governed by its annual revenue. After allowing for recurrent expenditure, development and maintenance programs are undertaken. At the end of the year, there is usually some unspent balance known as closing balance. This balance is sometimes a large amount, if the Corporation fails to utilize all the money within the fiscal year that includes own source revenue and government grant. Due to differential rates of grant receipts in different years, the absorption capacity for development projects varies from year to year. The total wage bill of the Corporation along with the repair and maintenance expenses, totaled Tk.955000 (in thousand) in 2005-06 financial year.

Table 4: Summary of Budgeted expenditure (in thousand)

\begin{tabular}{|c|c|c|c|}
\hline Financial year & Revenue expenditure & Other expenditure & Development expenditure \\
\hline $2001-02$ & $25.67 \%$ & $7.84 \%$ & $66.49 \%$ \\
\hline $2002-03$ & $27 \%$ & $6.21 \%$ & $66.78 \%$ \\
\hline $2003-04$ & $25.25 \%$ & $3.55 \%$ & $71.19 \%$ \\
\hline $2004-05$ & $22.71 \%$ & $3.03 \%$ & $74.26 \%$ \\
\hline $2005-06$ & $28.67 \%$ & $3.31 \%$ & $68.02 \%$ \\
\hline
\end{tabular}

Source: Field survey, 2009

Table 4 presents the summary of budgeted expenditure for the five financial year from 2001-02 to 2005-06. The data for every head shows that the share percentage of development expenditure is more than the revenue and other expenditure. The share of revenue expenditure in the financial year 2001-02 was only $25.67 \%$ of the total budgeted expenditure. Now the share of revenue expenditure has increased slightly to $28.67 \%$ of the total budgeted expenditure in the financial year 2005-06.

\section{Revenue Problems}

No Reassessment of General Valuation of Property/Holding Tax: This most important item of DCC income has not been revised regularly, even though the law requires the tax to be reassessed at five-year intervals to keep it at par with the prevailing market rate. Even when it is revised, in many cases, assessments are not done at the prevailing market rates. The last assessment has been carried out in 1989.

Lack of Transparency of Assessment: The assessment system is not transparent to a very large section of the taxpayers. Many taxpayers resent this and are reluctant to pay. They adopt various means of evading it in collusion with some of the officials concerned. Low assessment leads to low collection.

In Case of Rate and Fees: Like property assessment, rates of fees and rates are not also fixed correctly and they are not raised upward after increase of property value or business transactions. These result in huge loss of potential revenue. (Ahmed, 1992) 


\section{General Problems}

Constant Budget Revision: Despite revising its budget each year, DCC has failed to achieve even the revised target. In practice, DCC usually prepares its original budget on the basis of a 10 percent increase over the previous year. They do not take actual income and expenditure patterns into account while projecting the budget. They do not even consider using average method for projecting future income and expenditure, though this is a widely used statistical tool.

Untimely Submission of Budgets: DCC is reluctant to submit its budget to the Ministry on time. Similarly, the Ministry is less than serious about examining the budget and taking appropriate action on time. Part of the problem is that DCC's financial system is complex in nature because responsibilities are shared between central and local governments for various public sector functions.

Reluctance of People to Pay Taxes: The City Corporation dwellers are unenthusiastic to pay the taxes, because some dwellers are not provided by the utility services from the City Corporation. The authority cannot increase the tax rate due to their drawbacks for providing the adequate services.

Lack of Awareness: People do not pay, not because they are reluctant to pay but primarily because of lack of awareness among the tax payers. So, it will be very difficult to collect such tax if the rate of tax is increased.

Poor Socio-Economic Condition: In this research, socio-economic condition was investigated in the study area, where $35 \%$ is considered as ultra and poor, $25 \%$ in the lower middle, $33 \%$ in the middle-income and higher middle income group and only 7\% fall under the rich, depicting a picture that the community is likely to have of poorer affordability to pay tax for the Corporation services. So, if the rate of tax increases, people will feel it as a burden that will make a constraint to collect tax.

Political Intervention: Through the official interview, it was found that the local representative does not encourage tax collection on animal, marriages, school fees, hospital, clinic centre, fairs etc. for holding his good reputation, which is needed to win the next election. They feel that popularity of local representatives will be greater than before among the dwellers, if the tax rate is not increased. So it is clear that self esteem of local representatives get priority.

\section{New Potential Sources of Revenue}

- Revenue generation can be from a process on the sale of petroleum products, cigarettes and similar other products. The collection is done by the central authorities or passed on to the city corporation or collected by the latter directly.

- Tax on those places of worship (religious institution) whose part is used as commercial purpose can be imposed. It is investigated that tax is not collected on those places of worship (religious institution) whose part is used as commercial purpose although it is mentioned in the "City Corporation Model Tax Schedule 2002" that all places of worship whose part is used as commercial purpose will be assessed for imposing tax.

- Sumptuary taxes on cigarettes and other tobacco products may also bring in a substantial sum of money for the city corporation. For example, a dated estimate shows that by 1990, such sumptuary taxes alone could arise about taka 1074 million of which the Corporation share could be about taka 215 million (Asaduzzaman,1998).

\section{Future Needs}

Need for a Continuous Assessment Process: It is necessary to carry out fresh assessments in the City Corporation, where reassessment was not carried out in the last five years. A three yearly reassessment cycle would be a better idea in place of the present five yearly assessments. This will help update assessment value more frequently. A change in laws is required to introduce three yearly reassessment cycles. Periodic assessment, that is, assessment in between two reassessments 
should be carried out to capture those properties whose rental rate has significantly increased and whose occupancy status has changed from owner to rental (Ahmed, 1992).

Accountability of Tax Assessment Personnel for Property Valuation: To carry out the accurate assessment, number of surveyors as deemed necessary should be sanctioned and approved by the Mayor of the City Corporation. By their help, the assessor and assistant assessor assess the value according to the current assessment registers and all other information to new buildings and new establishments. Then the assessor will report any change in structure or any new construction to the chief executive officer or secretary for revised property valuation or addition to the tax roll. Extensive training is a crucial demand for the employee involved in the assessment procedure. So, it should be provided by a central training organization.

Raising Awareness among the Inhabitants of the City Corporation about Tax Assessment: There is urgency of raising awareness among tax payer as to how tax amount is calculated and about the relationship between Corporation's service delivery and tax payment. Apparently, only a miniscule minority knows how to tax is calculated. However, a substantial proportion of residents are aware of the relationship between better Corporation service delivery and tax receipts.

Exempting the Poor from Paying Holding Tax: On equity consideration, holdings having very poor quality dwelling could be exempted from paying holding tax altogether, and/or a fixed taka amount could be deducted from the assessed amount of holding tax thus making it somewhat progressive (UNDP, 1966).

Improving the Computerized Database System: A computerized Management Information System should be introduced and a central database at DCC headquarters should be established for networking with field offices. Computerized database system of all records related to taxes and revenue collection should be improved. For this purpose, two types of database would have to be prepared using data base software like MS Excel, MS Access, SPSS software etc.

Introducing a Reward System: A system of reward or commission for collectors upon fulfilling the targeted demand and punishment for poor performers should be introduced.

Raising Rebate Rates: The percentage of regular taxpayers enjoying rebates is $25-30$ percent. Another 25-35 percent pays their tax by persuasion, and the rest (30-35 percent) usually evade payment. The situation may be improved by increasing the rebate rate further. For the second category, the surcharge should be higher than the bank interest rate (20-25 percent) and for the third category action described under Section 72 (3) of DCC's Ordinance of 1983 may be taken by selling off some of their immovable property. At the same time, the system of seizure of moveable properties should be intensified.

Establishing Legal Action against Defaulters: Govt. empowered the City Corporation to recover all arrear through distress warrant, sale of movable property or even by attachment and sale of immovable property belong to the person concerned. City Corporation should not only serve the distress warrant but also take legal action against defaulters to collect arrear dues (Ahmed, 1992). Without punitive measures, collection efficiency could not be increased. City Corporation should bring pressure to bear on the defaulter to clear their arrears and should use the power which is provided by the government against the tax defaulters through attaching movable properties etc. City Corporation must understand that without a collection-lead strategy, no amount of reform in the system would generate tax revenues for them (UNDP, 1966).

Making the Billing System Easy: Investigation reveals that tax bills are not regularly handed over to the tax payers in the study area. Billing system should be computerized and the responsible authority will have to be put to a great concentration to handover the bill to the tax payer.

Updating the Tax Collection Records: Property records and tax collection records should be kept up-to-date. Regular posting of tax collection information on tax registers allows for checking of payment status of a tax payer and make it possible to serve tax notice in time. This enables the tax payers to know their positions and provide information for rebates and penalties.

Introducing a Monthly Interest Rate on the Delinquent Amount: Introduce a system under which penalty for default would go up as default period lengthens. Under the current system, only 
one time penalty is imposed on the defaulters, providing incentives to delay tax payment as much as possible. Introducing a monthly interest rate; say $2 \%$ on the delinquent amount could be useful in this regard (UNDP, 1966).

Updating the Accounting and Budgeting Procedure: It is recommended that the City Corporation replaces the present single entry accounting system with double entry system. To do that, two preconditions are changing the existing regulations in local government accounts system and training up the accounts personnel. With improvements in accounting system required is logical classification of revenue and expenditure in order to make sound decisions regarding investments and cash management. Development and maintenance expenditure will be shown separately. So the accounts will be kept separately for market, shops and buildings. Special project, accounts will be separately maintained with every detail. The summary of accounts will be incorporated in the budget books. Budgeting system needs improvements in several respects. Firstly, annual budget-making will be undertaken as a part of a longer term plan of investment and resource generation. Realistic assumptions are expected from budget makers in regards of revenue earnings from internal sources. Three-monthly assumptions about expected revenue earnings may be made in line with quarterly billing systems for tax revenues in order to prepare revised budgets.

\section{Summary and Conclusion}

There are serious difficulties in the current system of municipal finance in Bangladesh. Although City Corporation has been given several revenue sources with revenue rising potential, and these assignments are largely consistent with general principles of decentralization, these sources have proven to be erratic and unreliable. The City Corporation has little incentive to increase their tax efforts and even less discretion in their choices of tax rates. For the most part, City Corporation remains heavily dependent on the national government for their revenues, and much uncertainty surrounds the levels of this support (World Bank, 1997). There is scope for improvement of revenue generation capabilities of the City Corporation. Systematic improvements in every aspect of the local bodies are needed for this. The public representatives will have to be more dynamic and conscious about the needs of the people and must find out the means to finance the required services and infrastructures. The solution of almost all the problems lie in terms of increased initiative with elected Corporation representatives and the permanent staff within the respective jurisdictions and not outside those. From the foregoing discussion, it is apparent that the City Corporation faces a lot of problems in carrying out their daily activities, which restrict them from providing services as envisaged under rule to the city dwellers. In such a circumstance, the government should give importance to the issues and take necessary steps for solution.

\section{References}

Ahmed, N. 1992. Municipal Finance in Bangladesh -An Investigation of Local Level Initiative, Unpublished $\mathrm{PhD}$ thesis, Department of Economics, Jahangirnagar University, Savar, Dhaka.

Asaduzzaman, M.1998. Municipal Finance in Non-Metropolitan Towns: An Agenda for Policy Action, Research Report No. 159. Dhaka: Bangladesh Institute of Development Studies.

Mondol, A. H.1987. "An Evaluation of Municipal Finance in Bangladesh: An Illustration of Five Towns", The Journal of Local Government, Vol.16 (1), pp. 120-144

Tareque, M. A. 1995. "Union Parishad: Some Aspects of its Management Problems", The Journal of Local Government, Vol.13 (1) pp. 30-55.

UNDP, 1966. Local Government in Bangladesh: An Agenda for Governance, Prepared for the Government of Bangladesh. Dhaka: United Nations Development Program (UNDP).

World Bank, 1997. Bangladesh Municipal Finance Management Sector Study. Washington DC: World Bank. 